\title{
PEMANFAATAN FOAMING AGENT DARI MINYAK SAWIT PADA BETON RINGAN
}

\section{FOAMING AGENT UTILIZATION OF PALM OIL FOR LIGHT WEIGHT CONCRETE}

\author{
Mukarramah Lubis, Ani Suryani *), Ika Amalia Kartika, Erliza Hambali \\ Departemen Teknologi Industri Pertanian, Fakultas Teknologi Pertanian, \\ Institut Pertanian Bogor \\ Kampus IPB Dramaga, Bogor 16680, Jawa Barat, Indonesia \\ Email: anisuryani@gmail.com
}

Makalah: Diterima 27 Juli 2019; Diperbaiki 6 Desember 2019; Disetujui 16 Desember 2019

\begin{abstract}
Foaming agent contains surfactant that facilitates formation of foam to reduce the surface tension of liquid so that it can easily form bubbles. This time, foaming agent is used to produce lightweight concrete. Surfactant can be produced from fatty acid of palm oil named potassium palmitate and natrium laurate. The aim of this study to formulate a foaming agentfor production of lightweight concrete that could form foam that has best performances. Foaming agent for lightweight concrete was made mixturing from surfactant of potassium palmite and sodium laurate, sodium silicate and water. Design of experiment used was Completely Randomized Factorial Design with $\alpha=5 \%$ and Duncan post hoc test with $\alpha=5 \%$. Analysis of variance showed consentration of surfactant and consentration of natrium silicate has significant effect in foam stability, foaming ability, foam size and surface tension.The best formulation of foaming agent was foaming agent made from $15 \%$ of surfactant, $5 \%$ of natrium silicate and $80 \%$ of water. Its performances was foam stability of $92.72 \%$, foaming ability of $173.33 \%$, foam size of $249.54 \mu \mathrm{m}$ and surface tension of $27.78 \mathrm{dyne} / \mathrm{cm}$.
\end{abstract}

Keywords: foaming agent, palm oil, surfactant, sodium silicate, lightweight concrete

\section{ABSTRAK}

Foaming agent adalah bahan yang mengandung surfaktan yang dapat menurunkan tegangan permukaan suatu larutan sehingga dapat membentuk busa. Saat ini foaming agent dibutuhkan sebagai bahan dalam pembuatan beton ringan. Surfaktan yang digunakan diperoleh dari reaksi antara asam lemak dari minyak sawit dengan senyawa alkali. Penelitian ini bertujuan untuk memformulasikan foaming agent untuk menghasilkan busa dengan kinerja terbaik. digunakan dalam pembuatan beton ringan. Formulasi foaming agent dilakukan dengan mencampurkan surfaktan dengan natrium silikat dan air. Metode yang digunakan adalah rancangan acak lengkap 2 faktorial $\alpha=5 \%$ dilanjutkan dengan uji Duncan pada $\alpha=5 \%$. Berdasarkan hasil sidik ragam menunjukkan kedua faktor yaitu konsentrasi surfaktan dan konsentrasi natrium silikat berpengaruh nyata terhadap 4 variabel respon diantaranya stabilitas busa, kemampuan pembusaan, tegangan permukaan dan diameter busa. Hasil menunjukkan formulasi paling baik yaitu foaming agent dengan konsentrasi surfaktan 15\%, natrium silikat 5\% dan air $80 \%$. Kinerja foaming agent terdiri dari stabilitas busa 92,72\%, kemampuan pembusaan $173,33 \%$ dan diameter busa $249,54 \mu \mathrm{m}$ serta tegangan permukaan 27,78 dyne $/ \mathrm{cm}$.

Kata kunci: foaming agent, minyak sawit, surfaktan, beton ringan, natrium silikat

\section{PENDAHULUAN}

Penggunaan beton ringan dalam bidang konstruksi meningkat seiring waktu. Keunggulan beton ringan dibanding beton konvensional adalah beratnya yang lebih ringan dapat mengurangi beban bangunan apalagi bangunan yang membutuhkan penopang berupa pondasi sehingga dapat menghemat bahan untuk struktur pondasi terutama untuk bangunan bertingkat. Bobotnya yang ringan dan ukuran yang besar menyebabkan pengerjaan bangunan menjadi lebih cepat dibandingkan dengan beton merah atau batako. Selain itu, penggunaan beton ringan adalah dapat memudahkan pengerjaan, ramah lingkungan, dan tahan lama.
Beton ringan adalah beton yang memiliki densitas antara $400-1850 \mathrm{~kg} / \mathrm{m}^{3}$ yang dibuat dengan penambahan foaming agent ke dalam adonan semen, pasir dan air (mortar) (Ramamurthy et al., 2009). Komponen utama dalam pembuatan beton ringan adalah semen, pasir dan air. Namun pada saat ini pada beton ringan telah ditambahkan beberapa jenis agregat yang bertujuan untuk mengurangi penggunaan semen dan pasir yang dapat mengurangi biaya produksi. Agregat yang dapat ditambahkan dapat berupa bentonit, fly ash, silika, dan bottom ash (Amran et al.,2015).

Foaming agent merupakan bahan yang mengandung surfaktan yang dapat menghasilkan busa dengan menurunkan tegangan permukaan suatu cairan. Penggunaan foaming agent pada beton ringan ditujukan untuk membentuk gelembung-gelembung 
udara pada mortar sehingga setelah mengeras menghasilkan pori-pori yang dapat menurunkan densitas beton ringan yang dihasilkan. Adanya udara pada beton juga menghasilkan sifat yang menghambat panas dan kedap udara (Amran et al., 2015).

Jenis-jenis foaming agent yang digunakan pada beton ringan yaitu foaming agent sintetik, hydrolyzed protein, protein based detergent, glue resin, soap resin dan saponin. Foaming agent paling banyak digunakan di industri yaitu foaming agent sintetik. Jenis foaming agent tersebut merupakan foaming agent yang terbuat dari minyak bumi yang tidak dapat diperbaharui. Sifat yang tidak menguntungkan dari foaming agent tersebut dapat diatasi dengan membuat foaming agent dari bahan terbarukan. seperti surfaktan yang berbasis minyak nabati. Salah satu minyak nabati yang potensial digunakan yaitu minyak sawit. Minyak sawit mengandung asam-asam lemak yang dapat dimanfaatkan sebagai bahan pembuat foaming agent, yaitu asam oleat, asam stearat, asam palmitat, asam miristat dan asam laurat yang jumlahnya cukup banyak. Selain itu produksi minyak sawit yang melimpah menjamin ketersediaan bahan baku.

Foaming agent untuk beton ringan yang telah dikembangkan adalah foaming agent yang terbuat dari garam asam lemak (surfaktan) sebagai komponen utama. Surfaktan diperoleh dari hasil proses penyabunan yaitu reaksi antara larutan basa dengan asam lemak turunan minyak sawit. Rivai et al. (2017) memanfaatkan asam-asam lemak sawit seperti asam laurat, asam palmitat dan asam oleat untuk mensintetis kalium palmitat dan natrium laurat, sebagai foaming agent yang ramah lingkungan dan memiliki kestabilan paling baik. Kalium palmitat dan natrium laurat dapat dikembangkan menjadi foaming agent yang digunakan pada proses pembuatan beton ringan.

Foaming agent yang baik digunakan pada pembuatan beton ringan adalah yang memiliki densitas rendah serta stabil dalam waktu yang lama (Ramamurthy et al., 2009; Amran et al., 2015). Menurut Gray (2010), foaming agent yang baik untuk beton ringan adalah foaming agent yang dapat menghasilkan busa yang kuat menahan campuran beton ringan dan stabil selama proses pencampuran. Penambahan bahan aditif pada formulasi dilakukan untuk memperoleh foaming agent yang kuat dan stabil.

Drainage dapat dihambat dengan meningkatkan ketebalan lapisan gelembung busa dengan penambahan partikel-partikel solid, salah satunya yaitu dengan penambahan partikel silika (Binks et al., 2005). Penggunaan silika pada foaming agent dapat disebut busa silikat yang terbentuk dari adanya penambahan larutan alkali silikat sebagai pengeras pada foaming agent. Larutan alkali secara efektif dapat mengeraskan busa dengan mencampurkan larutan alkali silikat bersama dengan surfaktan yang berperan sebagai foaming agent (Van Bonin et al., 1974). Alkali silikat yang dapat digunakan adalah natrium silikat dan secara komersial dikenal dengan nama water glass.

Tujuan dari penelitian ini yaitu menganalisis pengaruh konsentrasi surfaktan dan natrium silikat pada foaming agent untuk beton ringan, mendapatkan formulasi foaming agent terbaik berdasarkan pengaruh konsentrasi surfaktan dan konsentrasi natrium silika yang digunakan, dan menganalisis kinerja foaming agent yang dilakukan dengan pengujian stabilitas busa, kemampuan pembusaan, diameter busa, dan tegangan permukaan.

\section{BAHAN DAN METODE}

\section{Alat dan Bahan}

Bahan yang digunakan untuk formulasi foaming agent adalah kalium palmitat, natrium palmitat, air dan natrium silikat. Peralatan yang digunakan pada penelitian ini adalah homogenizer, timbangan analitik, gelas ukur, gelas piala, penangas, magnetik stirrer, densitymeter Anton Paar DMA 4500M, spinning drop tensiometer, mikroskop, penggaris, dan mixer.

\section{Metode Penelitian}

Formulasi Foaming Agent

Formulasi foaming agent dibuat dengan mencampurkan surfaktan kalium palmitat dan natrium laurat pada perbandingan (1:1) dan variasi konsentrasi $10 \%, 15 \%$ dan $20 \%$ dengan natrium silikat konsentrasi 3\%, 4\% dan 5\% dan selebihnya adalah air. Selanjutnya formulasi dihomogen dengan dipanaskan pada suhu $90^{\circ} \mathrm{C}$ sambil diaduk selama 30 menit. Analisis yang dilakukan yaitu kestabilan busa, kemampuan pembusaan, tegangan permukaan dan diameter busa.

Pengujian Stabilitas Busa dan Kemampuan Pembusaan (Goon et al., 1999)

Sebanyak $0,75 \mathrm{~g}$ sampel foaming agent diencerkan dengan $30 \mathrm{~mL}$ akuades dan diaduk dengan homogenizer selama 15 menit. Kemudian campuran dituang ke gelas ukur, dikocok 20 kali, dan diamati volume busanya pada menit ke-0, ke-15, ke-30 dan ke-45. Penetapan stabilitas busa dilakukan dengan cara sederhana, yaitu dengan cara pengukuran berdasarkan pemisahan dengan asumsi bahwa sistem busa yang sempurna bernilai 100 . Perhitungan :

$$
\begin{gathered}
\% \text { Stabilitas Busa }=\frac{\text { tinggi busa awal }}{\text { tinggi busa akhir }} \times 100 \% \\
\% \text { Kemampuan Pembusaan }=\frac{\text { tinggi busa }}{\text { tinggi air }} \times 100 \%
\end{gathered}
$$




\section{Pengukuran Diameter Busa}

Sebanyak $0,75 \mathrm{~g}$ sampel foaming agent diencerkan dengan $30 \mathrm{~mL}$ akuades dan diaduk dengan homogenizer selama 15 menit. Kemudian campuran dikocok dengan mixer selama 5 menit. Busa yang dihasilkan diambil dengan sendok kemudian diletakkan pada kaca preparat selanjutnya dilihat dan diukur dengan mikroskop dengan pembesaran 40 kali.

Tegangan permukaan (Metode Spinning Drop: SBRC, 2013)

Pengukuran tegangan permukaan dilakukan dengan menggunakan alat spinning drop tensiometer. Sampel sebanyak $50 \mathrm{~mL}$ dilarutkan dengan konsentrasi $2,5 \%$ kemudian kemudian sampel dimasukkan ke dalam tabung hingga hampir penuh tetapi sisakan sedikit ruang untuk udara didalamnya kemudian tabung ditutup dan dimasukkan ke dalam alat spinning drop tensiometer. Suhu diatur pada $30^{\circ} \mathrm{C}$ dengan kecepatan rotasi alat ditetapkan pada $6000 \mathrm{rpm}$. Nilai tegangan permukaan sampel diperoleh dari nilai diameter gelembung udara didalam tabung yang kemudian dikonversikan menjadi tegangan permukaan oleh alat.

\section{Analisis Data}

Rancangan yang digunakan pada penelitian ini adalah rancangan acak lengkap (RAL) faktorial dengan 2 faktor yaitu konsentrasi surfaktan dan konsentrasi natrium silikat. Faktor konsentrasi surfaktan terdiri dari 3 taraf diantaranya 10\%, 15\%, $20 \%$ dan konsentrasi natrium silikat terdiri dari 3 taraf yaitu $3 \%, 4 \%, 5 \%$.
Percobaan dilakukan dengan 2 kali ulangan. Data yang diperoleh dianalisis menggunakan ANOVA pada $\alpha=5 \%$, untuk mengetahui perbedaan perlakuan dilakukan uji lanjut Duncan pada $\alpha=5 \%$. Model matematika dalam percobaan sebagai berikut

$$
Y_{i j k}=\mu+A_{i}+B_{j}+(A B)_{i j}+\varepsilon_{i j k}
$$

Dimana $\left(\mathrm{Y}_{\mathrm{ijk}}\right)$ variabel respon/hasil, $(\mu)$ pengaruh rata-rata sebenarnya, $\left(A_{i}\right)$ pengaruh dari faktor konsentrasi surfaktan taraf ke-I, $\left(B_{j}\right)$ pengaruh dari faktor konsentrasi natrium silikat taraf ke$\mathrm{j},\left[(\mathrm{AB})_{\mathrm{ij}}\right]$, pengaruh interaksi antar faktor konsentrasi surfaktan taraf ke-i dengan faktor konsentrasi natrium silikat taraf ke-j, $\left(\varepsilon_{\mathrm{ijk}}\right)$ pengaruh galat/error dari faktor konsentrasi surfaktan taraf ke-i, faktor konsentrasi natrium silikat taraf ke-j, ulangan ke-k.

\section{HASIL DAN PEMBAHASAN}

\section{Stabilitas Busa}

Stabilitas busa merupakan parameter yang menunjukkan kemampuan busa mempertahankan parameter utamanya (bentuk busa, ukuran busa, jumlah cairan dan volume busa) dalam selang waktu tertentu. Pengujian ini lebih merajuk pada perubahan volume busa yang dapat disimpulkan sebagai kemampuan busa untuk tetap mempertahankan gelembung-gelembungnya untuk tidak pecah. Hasil pengujian stabilitas busa formulasi foaming agent untuk beton ringan untuk selang waktu 15, 30 dan 45 menit dapat dilihat pada Gambar 1.

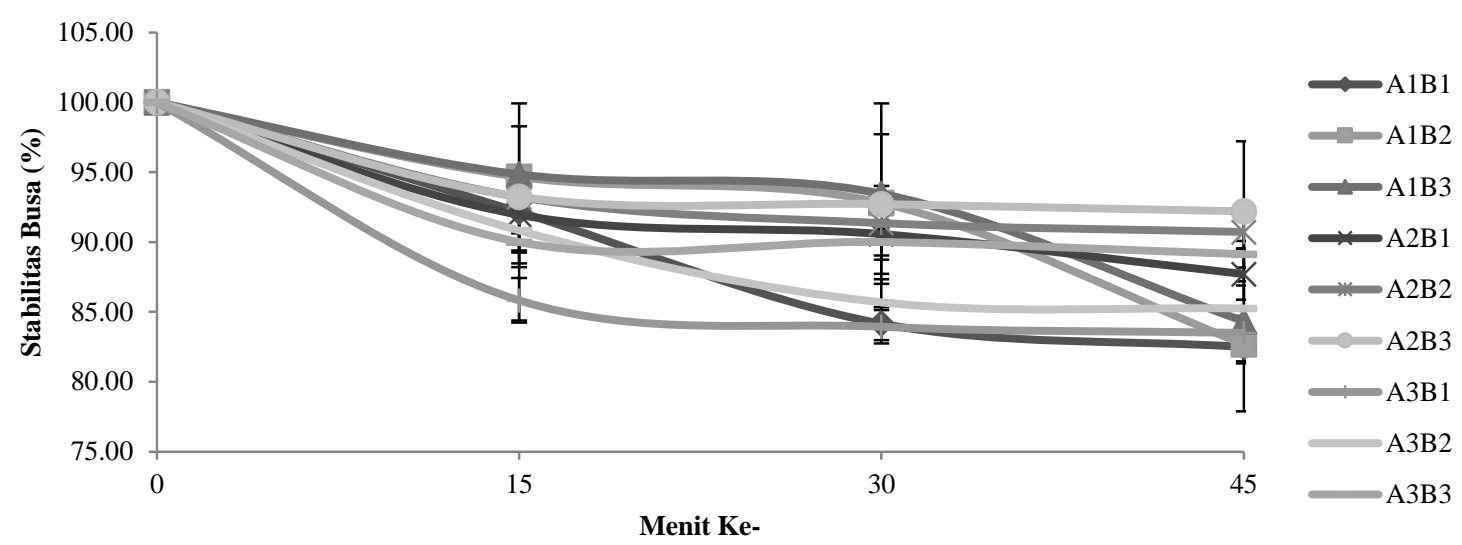

Ket :

A1B1 : Surfaktan 10\% dan natrium silikat 3\% A1B2 : Surfaktan 10\% dan natrium silikat 4\% A1B3 : Surfaktan 10\% dan natrium silikat 5\% A2B1 : Surfaktan 15\% dan natrium silikat 3\% A2B2 : Surfaktan 15\% dan natrium silikat 4\% A2B3 : Surfaktan 15\% dan natrium silikat 5\% A3B1 : Surfaktan 20\% dan natrium silikat 3\% A3B2 : Surfaktan 20\% dan natrium silikat 4\% A3B3 : Surfaktan 20\% dan natrium silikat 5\%

Gambar 1. Hasil pengujian stabilitas busa formulasi foaming agent 
Pengujian stabilitas busa menunjukkan semakin lama stabilitas busa semakin menurun. Penurunan nilai stabilitas busa disebabkan oleh berkurangnya kemampuan gelembung busa untuk mempertahankan bentuknya. Penurunan stabilitas busa berbeda pada setiap perlakuan. Semua perlakuan mengalami penurunan secara signifikan dari menit ke-0 hingga menit ke-15 sedangkan perlakuan A1B2, A1B3, A2B1 mengalami penurunan secara signifikan hingga ke menit ke-30. Stabilitas busa sebagian perlakuan tidak mengalami penurunan dari menit ke-15 hingga menit ke-30 namun pada menit ke-30 hingga menit ke-45 stabilitas busa turun secara signifikan.

Hasil pengujian stabilitas busa menunjukkan nilai stabilitas busa foaming agent semakin menurun seiring waktu yang semakin lama. Penurunan nilai stabilitas busa tersebut menunjukkan bahwa semakin lama terdapat gelembung-gelembung busa yang tidak dapat mempertahankan parameter utamanya seperti ukuran busa, jumlah cairan, dan total volume busa. Hal itu dapat disebabkan proses drainage, coarsening, dan coalescence (Tadros, 2005).

Hasil sidik ragam $(\alpha=0,05)$ menunjukkan bahwa konsentrasi surfaktan berpengaruh nyata terhadap stabilitas busa pada menit ke-30 dan 45 . Konsentrasi natrium silikat hanya berpengaruh nyata terhadap stabilitas busa pada menit ke-30. Interaksi antara konsentrasi surfaktan dan konsentrasi natrium silikat tidak berpengaruh nyata terhadap stabilitas busa. Hasil uji Duncan $(\alpha=0,05)$ untuk faktor konsentrasi surfaktan menunjukkan bahwa konsentrasi surfaktan $10 \%$ dan $20 \%$ tidak berbeda nyata sedangkan konsentrasi $15 \%$ berbeda nyata dengan konsentrasi surfakatan $10 \%$ dan $20 \%$. Hasil uji Duncan $(\alpha=0,05)$ untuk faktor konsentrasi natrium silikat pada menit ke-30 menunjukkan konsentrasi natrium silikat $3 \%$ berbeda nyata dengan konsentrasi natrium silikat $4 \%$ dan $5 \%$ sedangkan konsentrasi natrium silikat $4 \%$ dan $5 \%$ tidak berbeda nyata. Hasil pengujian stabilitas busa menunjukkan semua perlakuan mengalami penurunan seiring dengan waktu. Nilai stabilitas busa paling tinggi adalah perlakuan E yaitu dengan menggunakan surfaktan natrium laurat $30 \%$ dan kalium palmitat $70 \%$ pada hari ke-2 $(91,44 \%)$ dan ke-3 $(84,74 \%)$. Hasil sidik ragam $(\alpha=0,05)$ menunjukkan bahwa stabilitas busa tidak dipengaruhi oleh konsentrasi dan surfaktan baik pada hari ke-2 maupun pada hari ke-3.

Busa dengan stabilitas yang tinggi baik digunakan pada pembuatan beton ringan karena gelembung-gelembung busa yang dihasilkan menunjukkan kemampuan yang tidak mudah untuk pecah. Sifat tersebut menyebabkan busa tidak akan pecah ketika dilakukan pencampuran bahan-bahan campuran beton ringan seperti semen dan pasir (Amran et al., 2015). Perlakuan dengan nilai stabilitas busa tertinggi yaitu A2B3 pada menit ke-
45 yaitu 92,20\%. A2B3 adalah foaming agent dengan konsentrasi surfaktan $15 \%$ dan natrium silikat 5\%. Hal ini menunjukkan bahwa konsentrasi surfaktan terendah dan tertinggi menghasilkan nilai stabilitas busa yang lebih rendah. Konsentrasi surfaktan yang terlalu tinggi menghasilkan nilai stabilitas busa yang rendah diakibatkan terjadinya efek Gibbs-Marangoni. Efek Gibbs-Marangoni adalah keadaan surfaktan yang berlebihan akan menyebabkan terdapat surfaktan tidak terikat dengan udara. Surfaktan tersebut terdapat di antara gelembung-gelembung udara. Surfaktanakan mengganggu ikatan surfaktan dan udara sehingga membuat lapisan gelembung busa pecah.

Nilai stabilitas busa foaming agent komersial ADT masih lebih tinggi dibandingkan dengan A2B3 yaitu sekitar 98,05\% pada menit ke$15,95,53 \%$ pada menit ke-30 dan menit ke-45. Foaming agent yang dihasilkan memiliki stabilitas busa yang lebih tinggi jika dibandingkan dengan foaming agent yang telah dilakukan oleh Rivai et al. (2017) yang hanya menggunakan kalium palmitat yaitu $81,2 \%$. Tingginya nilai stabilitas busa A2B3 dikarenakan jumlah konsentrasi surfaktan yang digunakan lebih tinggi dan adanya penambahan natrium silikat.

\section{Tegangan Permukaan}

Tegangan permukaan merupakan suatu tegangan yang terjadi antara molekul-molekul yang terdapat di permukaan larutan dan tidak terdapat pada molekul yang berada di dalam larutan. Surfaktan adalah bahan yang memiliki peranan menurunkan tegangan permukaan cairan sehingga dapat membentuk gelembung-gelembung busa. Hasil sidik ragam $(\alpha=0,05)$ menunjukkan bahwa faktor konsentrasi surfaktan dan konsentrasi natrium silikat berpengaruh nyata terhadap tegangan permukaan larutan foaming agent. Hasil uji lanjut $(\alpha=0,05)$ menunjukkan konsentrasi surfaktan $10 \%$ dan $15 \%$ berbeda nyata dengan konsentrasi $20 \%$ sedangkan konsentrasi natrium silikat berbeda nyata pada semua perlakuan. Interaksi konsentrasi surfaktan dan konsentrasi natrium silikat berpengaruh nyata pada tegangan permukaan larutan foaming agent.

Peranan surfaktan adalah menurunkan tegangan permukaan suatu cairan untuk dapat menghasilkan gelembung-gelembung busa. Pada penelitian ini cairan yang diturunkan tegangan permukaannya adalah cairan air yang memiliki tegangan permukaan sebesar 72 dyne/cm. Nilai tegangan permukaan foaming agent paling rendah dihasilkan dari perlakuan dengan konsentrasi surfaktan sebesar $20 \%$ dan konsentrasi natrium silikat sebesar $3 \%$ yaitu 26,24 dyne/cm. Hasil pengujian tegangan permukaan untuk foaming agent komersial ADT menunjukkan nilai yang lebih tinggi yaitu 26,55 dyne/cm. 

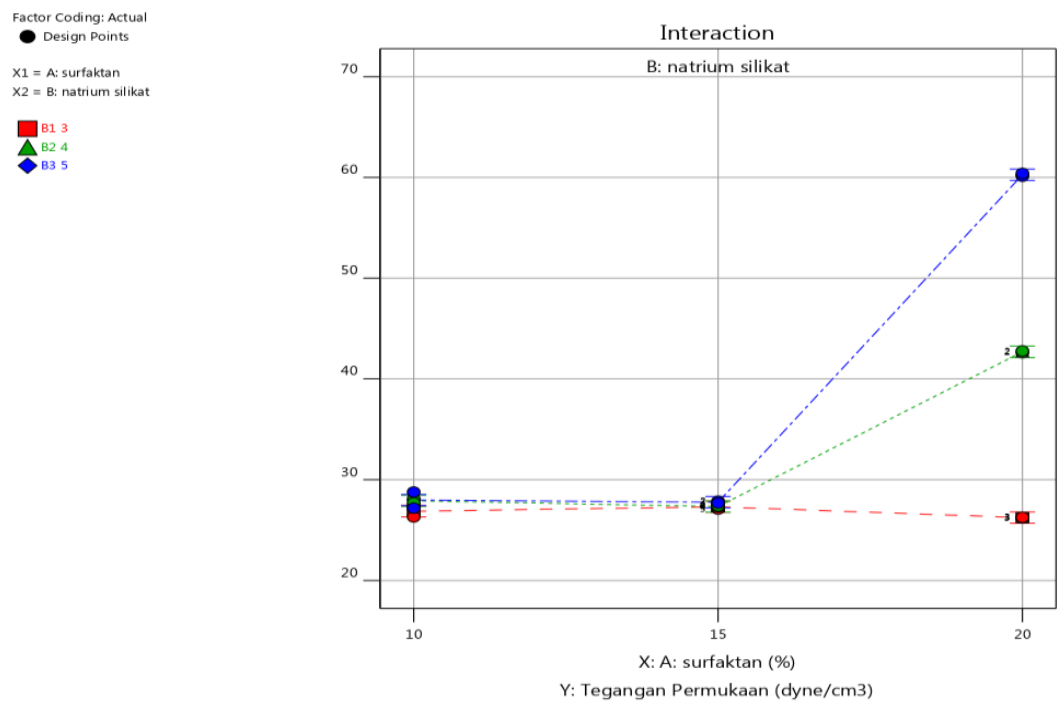

Figure 2. Interaction between surfactant consentration and sodium silicate consentration to surface tension of foaming agent

Tegangan permukaan foaming agent yang dihasilkan lebih besar dibandingkan dengan foaming agent Rivai et al. (2017) yaitu berkisar antara 0,939,85 dyne/cm dengan surfaktan yang digunakan berupa sabun dari asam lemak minyak sawit diantaranya kalium palmitat dan natrium laurat. Hal ini menunjukkan bahwa adanya penambahan bahan natrium silikat meningkatkan tegangan permukaan larutan. Menurut Gillian (1976), natrium silikat tidak memiliki kemampuan untuk menurunkan tegangan permukaan larutan.

Hasil pengujian tegangan permukaan menunjukkan adanya interaksi antara konsentrasi surfaktan dan konsentrasi natrium silikat pada hasil yang diperoleh. Interaksi kedua faktor dapat dilihat pada Gambar 2. Semakin tinggi konsentrasi surfaktan kemampuan menurunkan tegangan permukaan yang lebih tinggi. Sedangkan semakin tinggi konsentrasi natrium silikat kemampuan foaming agent untuk menurunkan tegangan permukaan semakin rendah. Nilai tegangan permukaan secara signifikan meningkat pada konsentrasi surfaktan $20 \%$ dan konsentrasi natrium silikat $4 \%$ dan $5 \%$. Hal ini menunjukkan bahwa penambahan natrium silikat pada foaming agent menghambat peran surfaktan untuk menurunkan tegangan permukaan cairan. Natrium silikat merupakan partikel yang yang ditambahkan untuk menyelubungi gelembung-gelembung busa. Namun dengan adanya lapisan partikel tersebut dapat menambah ketebalan lapisan cairan yang dapat menghambat surfaktan untuk menurunkan tegangan permukaan cairan (Stocco et al., 2011).

\section{Kemampuan Busa}

Kemampuan pembusaan merupakan parameter yang disajikan dalam bentuk persen yang menunjukkan kemampuan suatu cairan surfaktan untuk menghasilkan busa. Pengujian kemampuan pembusaan merupakan perbandingan tinggi busa dengan tinggi cairan kemudian disajikan dalam bentuk persen. Parameter ini menunjukkan banyaknya busa yang dapat dihasilkan pada jumlah volume cairan tertentu. Pada pembuatan beton ringan foaming agent yang baik dapat menghasilkan busa yang banyak. Formulasi foaming agent yang digunakan diencerkan dengan konsentrasi 2,5\% dalam air. Pengujian kemampuan pembusaan dilakukan pada menit ke-0, 15, 30 dan 45 untuk melihat perubahan jumlah busa pada selang waktu tertentu. Hasil pengujian kemampuan pembusaan dapat dilihat pada Gambar 3.

Hasil sidik ragam $(\alpha=0,05)$ menunjukkan bahwa konsentrasi surfaktan berpengaruh nyata terhadap kemampuan pembusaanfoaming agent untuk setiap waktu pengujian. Sedangkan konsentrasi natrium silikat dan interaksi kedua faktor tidak berpengaruh nyata terhadap kemampuan pembusaan. Hasil uji Duncan $(\alpha=0,05)$ untuk konsentrasi surfaktan menunjukkan bahwa seluruh konsentrasi surfaktan saling berbeda nyata.

Nilai kemampuan pembusaanfoaming agentyang dihasilkan berkisar dari 159,49\% $905,73 \%$. Perlakuan dengan nilai paling tinggiadalah konsentrasi surfaktan sebanyak $20 \%$ dan konsentrasi natrium silikat sebanyak 5\%. Hasil pengujian kemampuan pembusaanfoaming agent komersial ADT dan foaming agent hasil Rivai et al. (2017) menunjukkan nilai yang lebih rendah yaitu berkisar $202,13-270 \%$ dan $19,51 \%-170,73 \%$. Hal tersebut menunjukkan foaming agent yang dihasilkan menghasilkan busa yang lebih banyak dan dibandingkan dengan foaming agent yang lainnya. Hal ini karena konsentrasi surfaktan yang digunakan lebih tinggi. 
Kemampuan busa menunjukkan penurunan nilai seiring waktu pengujian. Semakin lama waktu menunjukkan penurunan kemampuan busa foaming agent.Pada menit 0 ke menit 15 terjadi penurunan yang signifikan. Hal ini menunjukkan pada menit ke-15 busa-busa yang dibentuk pada awal pengujian telah mengalami pecah. Setelah menit ke-15 menunjukkan nilai kemampuan busa menunjukkan nilai yang stabil. Hal ini menunjukkan bahwa busa telah stabil pada menit ke-15. Pecahnya gelembunggelembung busa yang dihasilkan disebabkan oleh terjadinya proses drainage, coarsening, dan coalescence (Tadros, 2005). Proses drainage adalah proses pecahnya gelembung busa akibat adanya perbedaan arah aliran zat air dan udara. Aliran cairan akan cenderung menuju ke arah dasar larutan karena dipengaruhi oleh gaya gravitasi. Aliran udara yang terdispersi bergerak ke arah permukaan cairan. Proses coarsening adalah proses terjadinya difusi udara yang terdispersi pada setiap gelembung busa. Hal ini akan menyebabkan bersatunya gelembunggelembung busa untuk bergabung membentuk gelembung yang lebih besar. Proses ini akan menyebabkan proses coalescence yaitu terjadinya proses penipisan lapisan gelembung busa. Proses ini menyebabkan gelembung pecah karena lapisan tidak dapat menahan aliran air dan udara pada gelembung busa.

\section{Diameter Busa}

Diameter busa merupakan parameter yang sangat mempengaruhi sifat busa yang dihasilkan. Pengujian dilakukan dengan menggunakan mikroskop dengan perbesaran 40 kali. Makin kecil ukuran gelembung busa yang dihasilkan dapat meningkatkan stabilitas busa. Hasil pengukuran diameter busa dapat dilihat pada Gambar 4.

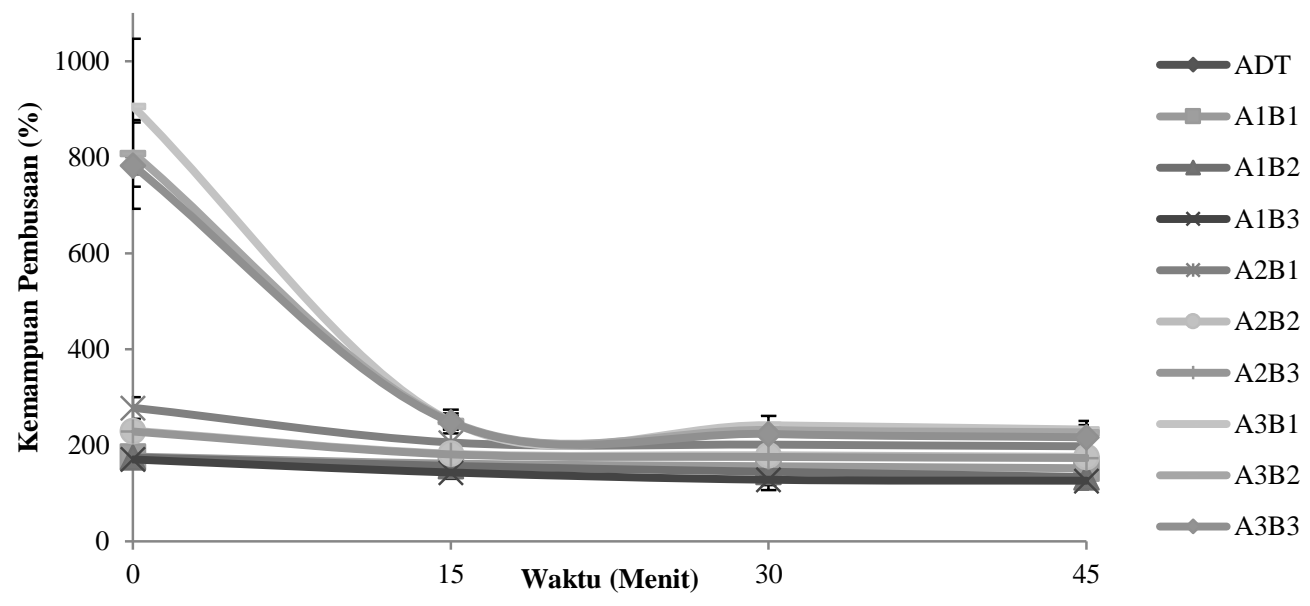

Gambar 3. Hasil pengujian kemampuan pembusaan

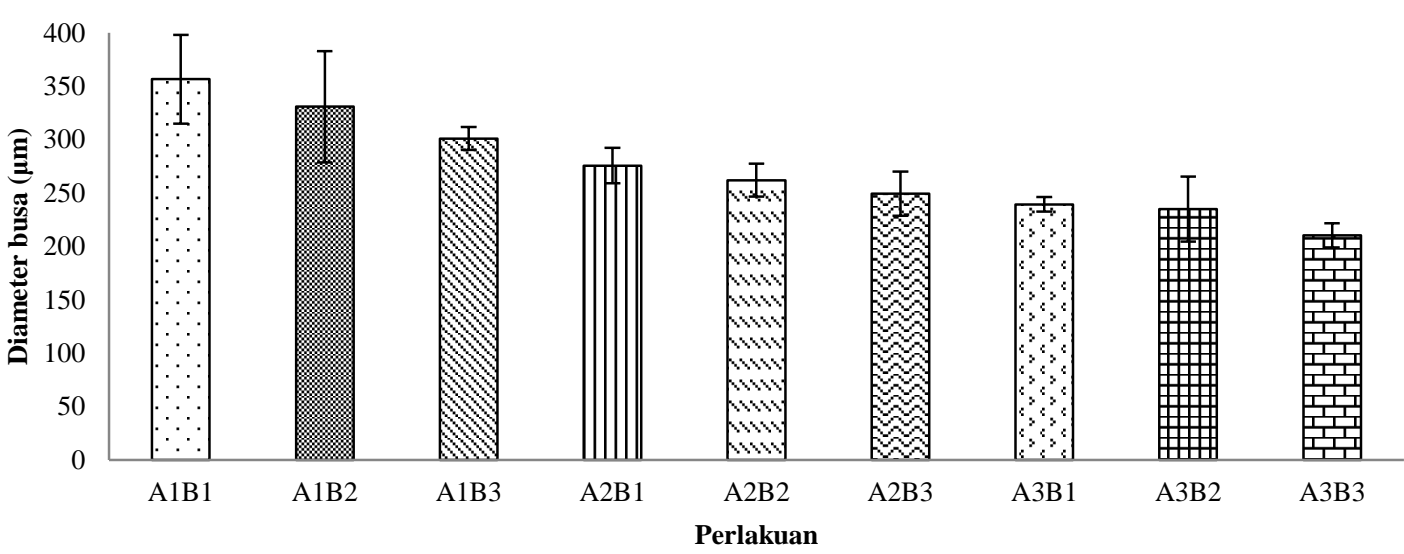

Gambar 4. Hasil pengukuran diameter busa 
Hasil sidik ragam $(\alpha=0,05)$ menunjukkan bahwa faktor konsentrasi surfaktan dan konsentrasi natrium silikat berpengaruh nyata terhadap diameter busa yang yang dihasilkan sedangkan untuk interaksi antara kedua faktor tidak berpengaruh nyata. Uji Duncan $(\alpha=0,05)$ menunjukkan hasil yang berbeda nyata untuk semua konsentrasi surfaktan. Uji Duncan $(\alpha=0,05)$ untuk konsentrasi natrium silikat menunjukkan bahwa konsentrasi natrium silikat 3\% berbeda nyata dengan $4 \%$ dan $5 \%$.

Hasil pengukuran menunjukkan bahwa semakin tinggi konsentrasi surfaktan dan natrium silikat yang digunakan pada formulasi foaming agent menghasilkan gelembung busa yang lebih kecil. Perlakuan yang menghasilkan ukuran busa paling kecil yaitu A3B3 (konsentrasi surfaktan 20\% dan natrium silikat 5\%) yaitu 210,41 $\mu \mathrm{m}$. Busa yang dihasilkan memiliki ukuran yang lebih kecil dari busa yang dihasilkan dari foaming agent komersial ADT yaitu 760,82 $\mu \mathrm{m}$. Ukuran diameter busa lebih kecil dari foaming agent yang dihasilkan Binks et al. (2005) yaitu sekitar $5-50 \mu \mathrm{m}$, ukuran yang lebih kecil karena menggunakan silika dengan ukuran nano serta konsentrasi yang lebih banyak yaitu sekitar $32 \%$.

Menurut Ramamurthy et al. (2009), busa yang baik dalam pembuatan beton ringan yaitu busa dengan ukuran kurang dari $1 \mathrm{~mm}$. Hal ini menujukkan bahwa busa semua perlakuanfoaming agent yang dihasilkan dapat digunakan dalam proses pembuatan beton ringan karena memiliki ukuran kurang dari $1 \mathrm{~mm}$. Ukuran diameter busa yang memiliki ukuran lebih dari $1 \mathrm{~mm}$ akan meningkatkan nilai porositas pada beton ringan sehingga akan menghasilkan beton yang tidak kuat. Selain itu juga busa dengan ukuran kurang dari 1 $\mathrm{mm}$ bersifat lebih stabil jika dicampurkan dengan adukan mortar.

Hal ini menunjukkan bahwa semakin tinggi konsentrasi surfaktan dan natrium silikat mempertebal lapisan gelembung-gelembung busa yang dihasilkan. Surfaktan berperan untuk menurunkan tegangan permukaan cairan, sehingga semakin tinggi konsentrasi surfaktan menghasilkan tegangan permukaan cairan yang lebih rendah. Rendahnya tegangan permukaan menunjukkan bahwa ikatan-ikatan molekul yang terdapat di permukaan cairan menjadi lebih lemah sehingga lebih mudah diikat oleh surfaktan dan menghasilkan gelembung - gelembung yang lebih kecil (Tadros 2005), sedangkan penggunaan natrium silikat bertujuan untuk meningkatkan lapisan yang melingkupi gelembung-gelembung busa sehingga dapat mempertahankan ukuran-ukuran busa dan mengurangi kemampuan busa untuk terjadi pecah atau terjadinya proses Ostwald ripening.

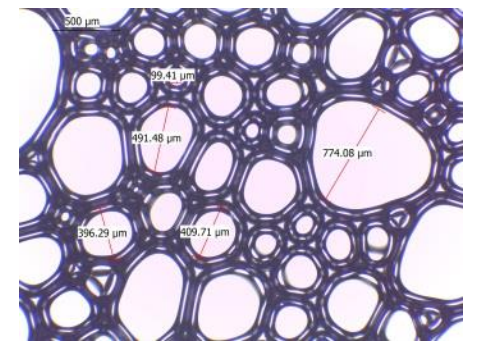

A1B1

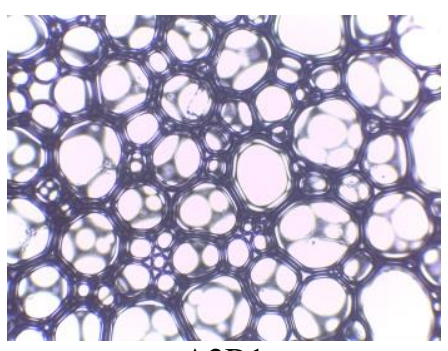

A2B1

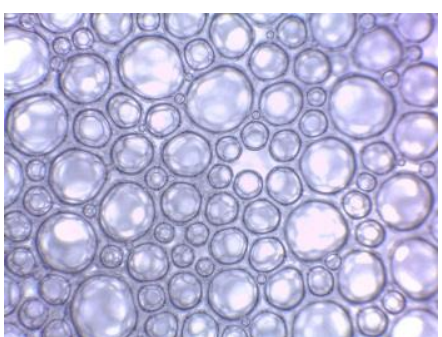

A3B1

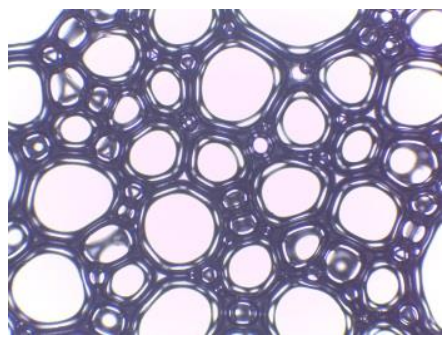

A1B2

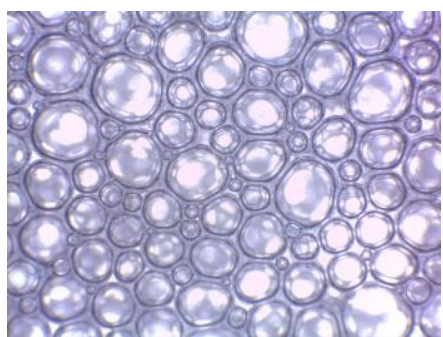

A2B2

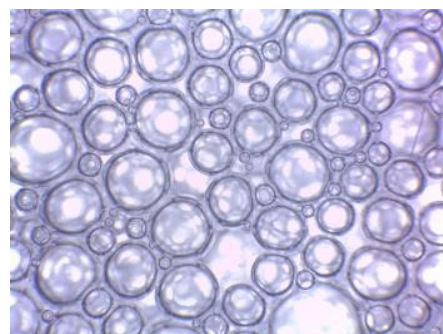

A3B2

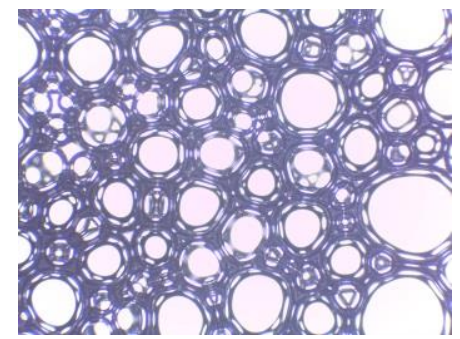

A1B3

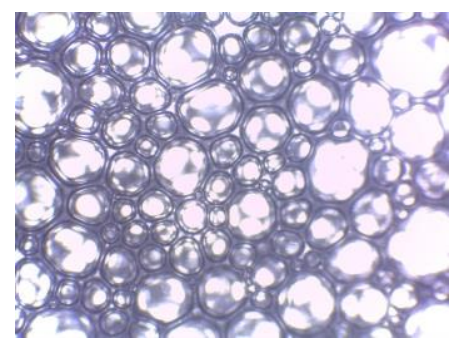

A2B3

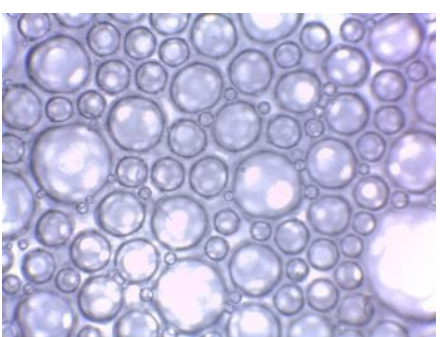

A3B3

Gambar 5. Penampakan gelembung foaming agent 
Ostwald ripening yaitu kejadian dimana zat terdispersi (gas) memiliki gaya saling tarik menarik sehingga dapat menyebabkan lapisan pendispersi (air) akan rusak. Rusaknya lapisan air memudahkan bersatunya molekul-molekul udara sehingga gelembung-gelembung yang terbentuk akan saling bersatu membentuk gelembung yang lebih besar yang sifatnya lebih mudah pecah.

\section{Penentuan Foaming Agent Terbaik}

Penentuan perlakuan terbaik menggunakan metode optimasi untuk desain faktorial pada aplikasi Design Expert 12 Trial. Metode optimasi dilakukan dengan menentukan kategori terbaik untuk semua respon yang diujikan. Kategori tersebut disebutkan sebagai fungsi tujuan untuk semua faktor. Pada penelitian ini terdapat 4 respon yaitu stabilitas busa, kemampuan pembusaan, diameter busa dan tegangan permukaan. Kinerja foaming agent terbaik pada nilai stabilitas busa dan kemampuan pembusaan yaitu foaming agent dengan nilai terbesar sedangkan untuk diameter busa dan tegangan permukaan yaitu foaming agent dengan nilai terkecil. Oleh karena itu, fungsi tujuan untuk respon stabilitas busa dan kemampuan pembusaan dikategorikan dengan nilai maksimasi sedangkan respon diameter busa dan tegangan permukaan dikategorikan dengan nilai minimasi. Hasil optimasi dapat dilihat pada Gambar 6.

Berdasarkan hasil sidik ragam $(\alpha=0,05)$ setiap respon diperoleh nilai $\mathrm{R}^{2}$ dan persamaan modelnya. Nilai $\mathrm{R}^{2}$ dan persamaan model respon menunjukkan pengaruh variabel $\mathrm{X}_{1}$ adalah konsentrasi surfaktan dan $\mathrm{X}_{2}$ adalah konsentrasi natrium silikat terhadap respon yang diujikan. Respon stabilitas busa menghasilkan nilai $\mathrm{R}^{2}$ sebesar 0,7182 yang mempunyai arti bahwa pengaruh variabel $\mathrm{X}_{1}$ dan $\mathrm{X}_{2}$ terhadap perubahan variabel respon adalah $71,82 \%$ sedangkan sisanya $28,18 \%$ dipengaruhi oleh variabel-variabel lain yang tidak diujikan. Menurut Pugh (1996) stabilitas busa juga dipengaruhi oleh keadaan lingkungan sekitar dari busa yang dibentuk. Busa yang telah dibuat cenderung mengalami pecah ketika suhu di lingkungan sekitar busa tinggi. Suhu yang tinggi menyebabkan ikatan antara surfaktan dan cairan menjadi lemah. Model untuk respon stabilitas busa yaitu $\mathrm{Y}=86,45+3,76 \mathrm{X}_{1}-0,23 \mathrm{X}_{2}+1,21 \mathrm{X}_{1} \mathrm{X}_{2}$. Berdasarkan model tersebut, dapat diketahui stabilitas busa akan meningkat ketika terjadi peningkatan konsentrasi surfaktan dan penurunan konsentrasi natrium silikat. Respon tegangan permukaan menghasilkan nilai $\mathrm{R}^{2}$ sebesar 0,999 yang mempunyai arti bahwa pengaruh variabel $\mathrm{X}_{1}$ dan $\mathrm{X}_{2}$ terhadap perubahan variabel respon adalah 99,9\% dan hanya $0,1 \%$ dipengaruhi oleh variabelvariabel lain yang tidak diujikan. Hal ini menunjukkan bahwa konsentrasi surfaktan dan natrium silikat sangat berpengaruh terhadap nilai tegangan permukaan foaming agent. Model untuk respon tegangan permukaan adalah $\mathrm{Y}=32,71$ $5,12 X_{1}+5,9 X_{2}+5,18 X_{1} X_{2}$. Berdasarkan model tersebut, dapat diketahui tegangan permukaan akan meningkat ketika terjadi penurunan konsentrasi surfaktan dan peningkatan konsentrasi natrium silikat. Respon kemampuan pembusaan menghasilkan nilai $\mathrm{R}^{2}$ sebesar 0,9142 yang mempunyai arti bahwa pengaruh variabel $\mathrm{X}_{1}$ dan $\mathrm{X}_{2}$ terhadap perubahan variabel respon adalah $91,42 \%$ sedangkan sisanya $8,58 \%$ dipengaruhi oleh variabelvariabel lain yang tidak diujikan. Model untuk respon kemampuan pembusaan adalah $\mathrm{Y}=181,95+$ $0,6 \mathrm{X}_{1}+2,78 \mathrm{X}_{2}+2,77 \mathrm{X}_{1} \mathrm{X}_{2}$. Berdasarkan model tersebut, dapat diketahui kemampuan pembusaan akan meningkat ketika terjadi peningkatan konsentrasi surfaktan dan konsentrasi natrium silikat.

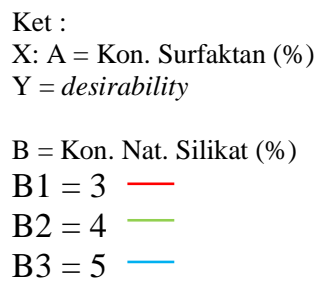

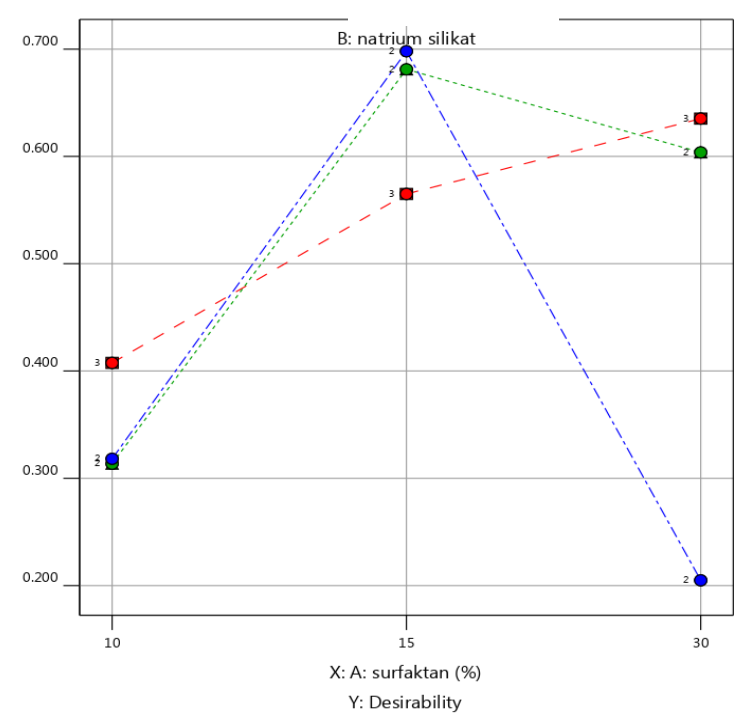

Gambar 6. Pengaruh konsentrasi surfaktan dan natrium silikat $\mathrm{h}$ terhadap nilai tegangan permukaan foaming agent 
Respon diameter busa menghasilkan nilai $\mathrm{R}^{2}$ sebesar 0,5889 yang mempunyai arti bahwa pengaruh variabel $\mathrm{X}_{1}$ dan $\mathrm{X}_{2}$ terhadap perubahan variabel respon adalah $58,89 \%$ sedangkan sisanya $41,11 \%$ dipengaruhi oleh variabel-variabel lain yang tidak diujikan. Menurut Kawale (2012) diameter busa juga dipengaruhi oleh metode dalam pembentukan busa yang dilakukan. Dalam penelitian ini metode pembentukan busa dilakukan dengan pengadukan dalam kecepatan tinggi. Kecepatan yang tinggi akan menyebabkan makin banyak gas yang dapat kontak dengan foaming agent sehingga menghasilkan diameter busa yang lebih kecil (Pugh 1996). Model untuk respon diameter busa adalah $Y$ $=266,41+32,86 X_{1}+12,25 X_{2}-33,51 X_{1} X_{2}$. Berdasarkan model tersebut, dapat diketahui diameter busa akan meningkat ketika terjadi peningkatan konsentrasi surfaktan dan konsentrasi natrium silikat.

Hasil yang terbaik menunjukkan nilai desirability yang lebih dari 0,95. Pada penelitian ini menunjukkan bahwa nilai desirability tertinggi yaitu 0,698. Nilai desirability dipengaruhi oleh nilai $\mathrm{R}^{2}$ untuk setiap respon. Nilai $\mathrm{R}^{2}$ untuk setiap respon yaitu stabilitas busa 0,7182 , tegangan permukaan 0,9990, kemampuan pembusaan 0,9142, dan diameter busa 0,5889 . Hal ini menunjukkan respon stabilitas busa dan diameter busa memiliki nilai $\mathrm{R}^{2}$ rendah yang berarti respon tersebut dipengaruhi oleh faktor selain dua faktor yang diujikan yaitu konsentrasi surfaktan dan konsentrasi natrium silikat. Menurut Pugh (1996) dan Kawale (2012), stabilitas busa juga dipengaruhi oleh keadaan lingkungan ketika busa dibentuk seperti suhu, dan kelembapan udara. Sedangkan diameter busa dapat dipengaruhi oleh kecepatan putaran yang digunakan ketika pembentukan busa dilakukan. Semakin banyak gas yang dapat kontak dengan foaming agent akan menghasilkan busa yang lebih kecil dan meningkatkan stabilitas busa yang dihasilkan.

Hasil optimasi yang diperoleh menunjukkan formulasi foaming agent terbaik yaitu foaming agent A2B3 dengan konsentrasi surfaktan $15 \%$ dan natrium silikat $5 \%$. Hasil terbaik tersebut diperoleh dari nilai desirability tertinggi dari semua nilai perlakuan yaitu sebesar 0,698 .

\section{KESIMPULAN DAN SARAN}

\section{Kesimpulan}

Penambahan surfaktan yaitu kalium palmitat dan natrium laurat berperan meningkatkan stabilitas busa dan kemampuan busa sedangkan natrium silikat memberikan pengaruh terhadap ukuran busa. Formulasi foaming agent yang paling baik adalah perlakuan A2B3 yaitu dengan konsentrasi surfaktan sebanyak $15 \%$, natrium silikat sebanyak $5 \%$ dan air $80 \%$. Stabilitas busa yang dihasilkan $92,72 \%$, kemampuan busa $173,33 \%$ dan diameter busa
249,54 $\mu \mathrm{m}$ serta tegangan permukaan 27,78 dyne/cm.

\section{Saran}

Penelitian mengenai alat dan metode dalam pembuatan busa masih perlu untuk dikaji lebih dalam lagi, karena kualitas busa juga sangat ditentukan oleh cara yang dilakukan dalam pembentukan busa.

\section{DAFTAR PUSTAKA}

Amran YH, Mugahed, Farzadnia N, Ali AA. 2015. Properties and applications of foamed concrete; a review. Construction and Building Materials. 101:990-1005

Binks BP, Horozov TS. 2015. Aqueous foams stabilized solely by silica nanoparticles. Angewandte Chemie. 117:3788-3791. doi: 10.1002/ange. 200462470

Gillilan W, penemu; Owens-Corning Fiberglas Corporation. 1976 Apr 20. Foamed products from sodium silicate. United States Patent US 404478Wiley VCH

Goon P, Bhirud RG. Kumar VV. 1999. Detergency and foam studies on linear alkybenzene sulfonate and secondary alkyl sulfonate. $J$ Surfactant Deterg. 2(4):489-493.

Gray LJ, Murray UT, penemu;Staker \& Parson Companies. 2010 Jun 10. Concrete mixtures having stabilized foam admixture. United States Patent US 0139523.

Kawale D. 2012. Influence of dynamicsurface tension onfoams: Application ingas well deliquification. [Tesis]. Delft (NE): Delft University of Technology.

Pugh RJ. 1996. Foaming, foam films, antifoaming and defoaming. Advances in Colloid and Interface Science. 64:67-142.

Ramamurthy K, Nambiar RK, Ranjani GIS. 2009. A classification of studies onproperties of foam concrete, Cem. Concr. Compos. 31(6):388396.

Rivai M, Hambali E, Suryani A, Fitria R, Firmansyah S, Pradesi J. 2017. Synthesis of palm oil fatty acid as foaming agent for firefighting application. IOP Conf. Ser.: Earth Environ. Sci. 65. doi :10.1088/17551315/65/1/012047.

Stocco A, Rio E, Binks BP, Langevin D. 2011. Aqueous foams stabilized solely by particles. Soft Matter. 7 : 1260-1267. doi : 10.1039/c0sm01290d.

Tadros TF. 2005. Applied surfactant: priciples and application. 259-263. Weinheim (DE) : Wiley VCH.

Van Bonin W, Nehen U, penemu; Bayer Aktiengesellschalt. 1974 Nov 26. Production of silicate foam. United States Patent US 318068 . 